Thorax (1968), 23, 621.

\title{
Aortic valve replacement with Dacron-supported grafts
}

\author{
D. A. WATSON, K. W. PEAR SON, J.C. CA W LEY, W. G. R HEA, \\ R. J. DONNELLY, AND F. DEXTER
}

From the Department of Thoracic Surgery, The General Infirmary at Leeds

\begin{abstract}
A method is described for inserting grafts on carrier rings in the aortic area when conditions for free grafting are not applicable, namely, dilated aortic root and friable aortic wall. In addition these grafts are suitable for use in the atrio-ventricular position. The results of 11 cases are presented; one early post-operative death occurred, the follow-up period being 3 to 6 months. It is shown that this method is practicable, the incidence of post-operative aortic incompetence may be reduced, and post-operative gradients do not occur if a valve of sufficient internal diameter is used.
\end{abstract}

Following pioneer work in both man and animals (Lam, Aram, and Munnell, 1952 ; Murray, 1956, 1960 ; Beall, Morris, Cooley, and DeBakey, 1961 ; Kerwin, Lenkei, and Wilson, 1962 ; Bigelow, Yao, Aldridge, Heimbecker, and Murray, 1964), the use of free aortic homografts in the subcoronary position has become established practice (Duran and Gunning, 1962; Ross, 1962, 1964, 1966 ; Barratt-Boyes, 1964, 1965 ; Barratt-Boyes, Lowe, Cole, and Kelly, 1965 ; Davies, Lessof, Roberts, and Ross, 1965 ; Paneth and O'Brien, 1966).

The advantages of free homografts compared with mechanical prostheses are now well known. The main disadvantages of free aortic homografts are :

(1) Procurement is difficult.

(2) In a dilated aortic root the maximum obtainable graft may be too small to permit insertion without producing incompetence.

(3) Progressive dilatation of the aortic root is likely to produce increasing incompetence of the cusps due to dilatation of the mobile valve ring, e.g., Marfan's syndrome (Ross, 1966).

(4) Distortion of the aortic wall, particularly by calcification, makes insertion of the free homograft difficult (Ross, 1966).

(5) Free homografts are unsuitable in the atrioventricular position.

(6) The long-term fate is uncertain, with particular concern about late calcification and fibrous thickening of the valve cusps (Ross, 1967 ; Hudson, 1966; Smith, 1967 ; Duran, Manley, and Gunning, 1965 ; Brock, 1968).
Various attempts have been made to overcome some of these difficulties, including (a) free heterografts ; $(b)$ autografting of the pulmonary valve ; and $(c)$ grafts on carrier rings.

(a) Immunological reactions to homografts were significantly absent (Davies et al., 1965), and this encouraged the use of heterografts which are freely available and offer a wide range of valve sizes. Experience with free heterografts is now considerable in man and animals; and if a sterilized, non-viable heterograft is used there appears to be no significant immunological response (Duran and Gunning, 1965 ; Binet, Duran, Carpentier, and Langlois, 1965 ; O'Brien and Gerbode, 1964; O'Brien and Clarebrough, 1966 ; O'Brien, 1967 ; O'Brien, Clarebrough, McDonald, Hale, Bray, and Cade, 1967). Thus it would appear that, from the immunological point of view, there is little to choose between non-viable homografts and heterografts, since both excite little or no immunological response in the host tissue. However, since non-viable heterografts have been in use a shorter period, their long-term fate is more uncertain. It has been suggested that viable grafts offer a better long-term prognosis; in particular, it appears that late calcification is less likely to occur if viable tissue is used (Brock, 1968). But viable heterografts, unlike viable homografts, excite a significant immunological response (Pritchard, Wright, and Johnston, 1967 ; Paton, Kwong, Clark, Halseth, and Hill, 1967), making them unsuitable for clinical use unless immunosuppression, with all its complications, be con- 
sidered (Kwong, Paton, and Hill, 1967). Unfortunately, the use of free heterografts overcomes only disadvantages (1) and (2) listed above.

(b) In an attempt to improve long-term fate, Ross (1967) used viable autogenous pulmonary valve grafts in the aortic position, and replaced the excised pulmonary valve with a homograft aortic valve. In this position the dead homograft is not subjected to pressures at systemic levels and is likely to have an improved long-term prognosis. Nevertheless, disadvantages (1) to (5) still remain.

(c) Homografts on non-thrombogenic carrier rings were first tried experimentally in animals in the mitral position (Weldon, Mel Ameli, Morovati, and Shaker, 1966) and repeated in the mitral and tricuspid areas (Braunwald, Fuchs, and Bonchek, 1967, 1968). Braunwald et al. (1967) suggested that these preparations might be suitable for use in the aortic area, and this was first reported in animals by Geha, Titus, and McGoon (1967). The advantages suggested were ease of insertion, use in large aortic roots too large for free homografts, and prevention of incompetence due to dilatation of the root, thus overcoming disadvantages (2) to (5). It seemed reasonable, therefore, to use this type of preparation in the aortic area in man.

The following is a report of our early experience of the clinical use of this type of preparation.

\section{METHOD OF PREPARATION}

Homograft aortic valves were collected from donors aged between 10 and 60 years, and, if free from calcification and atheroma, were accepted for use. Aortic heterografts were collected daily at the local abattoir from pigs weighing $150-250 \mathrm{lb}$. $(68-113 \mathrm{~kg}$.). All grafts were subjected to pressure testing and accepted if competent at a back pressure of $120 \mathrm{~mm}$. Hg. Internal and external diameters were measured with an obturator for the internal diameter and a calliper for the external diameter.

All valves were chemically sterilized with $1 \%$ beta-propiolactone at $37^{\circ} \mathrm{C}$. for two hours, and, following bacteriological aerobic and anaerobic sterility tests, were snap frozen at $-80^{\circ} \mathrm{C}$., freezedried, and stored in the Regional Tissue Bank (Rains, Crawford, Sharpe, Shrewsbury, and Barson, 1956). There is at present uncertainty about the best method of sterilization and preservation of valve graft material. We used this method for our valve preparation because it had been used for many years, and found to be satisfactory, for the preparation of arterial grafts in our Regional Tissue Bank.

When required for suturing, the graft was aseptically reconstituted in sterile physiological saline to which had been added 100 units $/ \mathrm{ml}$. penicillin and streptomycin, and 50 units $/ \mathrm{ml}$. heparin. Reconstitution was carried out several hours before suturing to the carrier ring to allow the graft to return to its original texture.

The aortic carrier ring consists of an inner titanium frame (Fig. 1) completely covered with 75 denier Dacron (Fig. 2).

Suture of the graft to the ring was carried out aseptically, in the theatre suite, the ring first being sterilized by autoclaving. The internal and external diameters of the ring were measured and recorded, using sterilized callipers. A reconstituted valve of external diameter equal to the internal diameter of the ring was then selected. The graft was first trimmed, following the commissure down around the attached margin of the cusp, retaining a small margin for insertion of sutures, leaving the lower margin below the cusps intact. The graft was then inserted inside the ring, and the upper edge was sutured to the upper edge of the ring. The redundant lower margin of the graft was afterwards trimmed to fit the lower margin of the ring, and was finally sutured to the

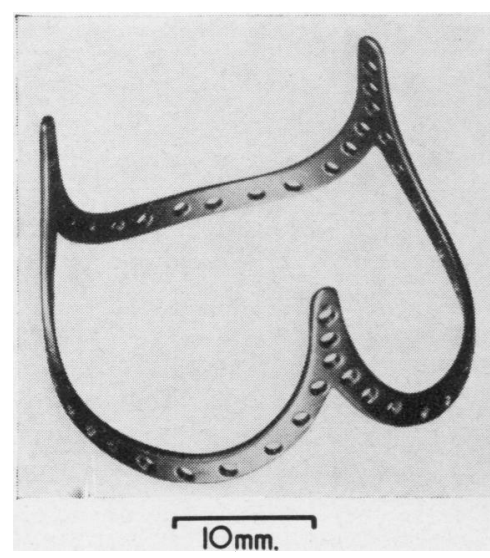

FIG. 1. Titanium ring.

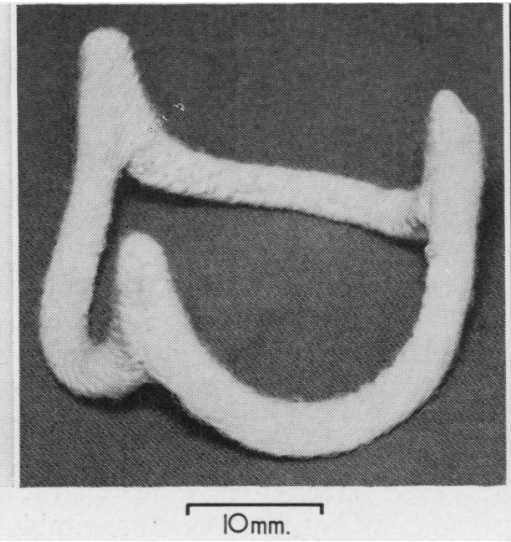

FIG. 2. Covered titanium ring.

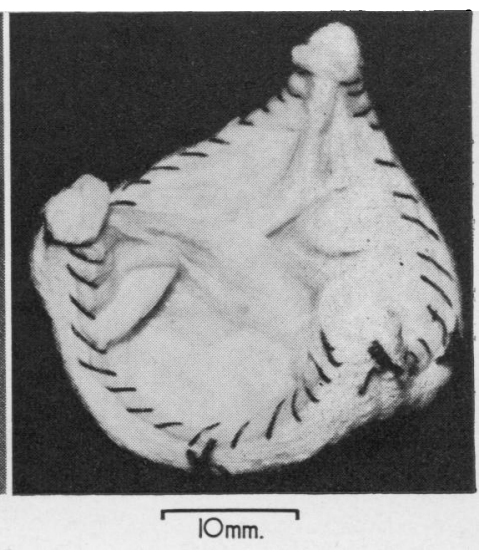

FIG. 3. Graft sown into ring. 
lower margin, using a continuous $4 / 0$ polyester suture. The completed aortic prosthesis was then as shown in Figure 3.

Finally, the internal diameter of the completed prosthesis was measured with callipers and noted along with the external diameter.

The completed prosthesis together with several segments of surplus aortic tissue were stored in a sterile jar containing normal antibiotic reconstitution fluid and returned to the Tissue Bank for storage in reinforced antibiotic solution at $4^{\circ} \mathrm{C}$. When the prosthesis was used the surplus aortic remnants were cultured to provide a complete check of the sterility of the preparation.

\section{CLINICAL MATERIAL}

Eleven patients were treated with 13 grafts on rings, cases 1 to 3 being aortic heterografts on rings in the aortic position, the remainder consisting of aortic homografts on rings, viz., cases 4 to 9 in the aortic position, and cases 10 and 11 in the aortic and mitral positions.

The series consists of 11 patients, six men and five women; five patients aged 40-50 years, three patients aged 50-60, two patients aged 30-40, and one patient aged 24 years.

The aetiology of the valve disease was as follows: four had a definite history of previous rheumatic fever, one of whom had associated active subacute bacterial endocarditis which caused acute aortic valve rupture necessitating emergency valve replacement. Four were thought to be rheumatic in origin, although there was no definite history of rheumatic fever. One of these had a past history of subacute bacterial endocarditis. One patient had congenital aortic stenosis, another had syphilitic aortic incompetence, and the remaining patient had aortic incompetence associated with Reiter's disease.

Seven patients had dominant aortic incompetence, two had dominant aortic stenosis, and two had mixed aortic valve disease. Associated valve lesions occurred in four patients, two of whom had mixed mitral disease, one with mitral and tricuspid stenosis and one with associated mitral stenosis.

PRE-OPERATIVE ASSESSMENT Cardiac symptoms have been graded I to IV (Barratt-Boyes, 1965):

Grade I-Asymptomatic

Grade II-Effort dyspnoea only

Grade III-Effort dyspnoea, angina of effort, and syncope

Grade IV-Congestive heart failure, paroxysmal nocturnal dyspnoea, orthopnoea, or angina decubitus.

Three patients had grade III symptoms; all three were cases of dominant aortic incompetence. The remaining eight patients had grade IV symptoms.

An electrocardiogram showed $\mathrm{LV}+++$ (LV $+++=T$ inversion and ST depression in left ventricle leads) in all the aortic valve replacement cases except one-the acutely ruptured valve due to subacute bacterial endocarditis. Eight patients were in sinus rhythm, of whom two had first degree heart block; three others had atrial fibrillation.

The cardiothoracic ratio was greater than $1: 2$ in all cases.

Respiratory and renal function tests were performed in most cases (Table I).

Liver-function tests and bromsulphalein excretion were performed; bilirubin was $1.2 \mathrm{mg} . / 100 \mathrm{ml}$. in

T A B L E I

PRE-OPERATIVE ASSESSMENT

\begin{tabular}{|c|c|c|c|c|c|c|c|c|c|}
\hline \multirow[b]{2}{*}{ Case } & \multirow{2}{*}{$\begin{array}{l}\text { Sympto- } \\
\text { matology }\end{array}$} & \multicolumn{2}{|r|}{ E.C.G. } & \multicolumn{2}{|c|}{$\begin{array}{l}\text { Respiratory } \\
\text { Function }\end{array}$} & \multicolumn{2}{|c|}{ Renal Function } & \multicolumn{2}{|c|}{ Liver Function } \\
\hline & & L.V.H. & Rhythm & $\begin{array}{l}\text { V.C. } \\
\text { (1.) }\end{array}$ & F.E.V.1\% & $\begin{array}{c}\text { Urea } \\
(\mathrm{mg} . / \\
100 \mathrm{ml} .)\end{array}$ & $\begin{array}{l}\text { Creatinine } \\
\text { Clearance } \\
\text { (ml./min.) }\end{array}$ & & Bromsulphalein \\
\hline 1 & III & $+t+$ & Sinus rhythm & $2 \cdot 9$ & 41 & 29 & 82 & Normal & $25 \min .2 \%$ \\
\hline 2 & III & $++t$ & Sinus rhythm & $3 \cdot 6$ & 83 & 19 & 103 & Normal & $25 \min .6 \%$ \\
\hline 3 & IV & ++ & $\begin{array}{l}\text { Sinus rhythm } \\
\text { 1st degree heart } \\
\text { block }\end{array}$ & $3 \cdot 2$ & 85 & 31 & 92 & Normal & $\begin{array}{l}25 \min .21 \% \\
45 \min .0 \%\end{array}$ \\
\hline 4 & IV & +++ & Sinus rhythm & 3.9 & 61 & 28 & 80 & Normal & $25 \mathrm{~min}$. \\
\hline 5 & IV & +++ & $\begin{array}{l}\text { Sinus rhythm } \\
\text { 1st degree heart } \\
\text { block }\end{array}$ & $2 \cdot 4$ & 87 & 47 & 108 & Normal & $\begin{array}{l}25 \min .12 \% \\
45 \min .5 \%\end{array}$ \\
\hline 6 & IV & +++ & Sinus rhythm & $2 \cdot 3$ & 52 & 40 & 55 & Normal & $25 \min .2 \%$ \\
\hline 7 & IV & $++t$ & Atrial fibrillation & 1.6 & 77 & 26 & 53 & Bilirubin $1.2 \mathrm{mg} . \%$ & $25 \mathrm{~min} .43 \%$ \\
\hline 8 & III & $++t$ & Sinus rhythm & $2 \cdot 9$ & 80 & 29 & 93 & Normal & 25 min. $12 \%$ \\
\hline 9 & IV & + & Sinus rhythm & & & 27 & & Normal & $25 \mathrm{~min}$. \\
\hline 10 & IV & +++ & Atrial fibrillation & $2 \cdot 8$ & 69 & 48 & & Normal & $25 \min .8 \%$ \\
\hline 11 & IV & $+t+$ & Atrial fibrillation & $3 \cdot 3$ & 77 & 34 & 64 & Normal & $25 \min .18 \%$ \\
\hline
\end{tabular}


one patient. Two patients had an abnormal bromsulphalein excretion; case 7 had associated mitral and tricuspid stenosis; and case 11 an associated mixed mitral lesion.

OPERATIVE DETAILs A median sternotomy incision was used in all cases of aortic and of combined aortic and mitral replacements. Pre-perfusion pressures were first recorded, and perfusion was started with the Pemco oxygenator, using total body perfusion. Both coronary arteries were cannulated and perfused through a transverse aortotomy incision.

The aortic valve was excised at the cusp attachment and the root measured with an obturator. A prosthesis of the same external diameter was selected and sutured into the aortic site with interrupted mattress sutures through the aortic wall and the outside of the valve ring, as shown in Figures 4 and 5 . The prosthesis was then pushed into position, and the sutures were tied. Finally, post-perfusion pressures were measured.

Nine aortic valve replacements were performed, one with an associated mitral and tricuspid valvotomy, and another with a closed mitral valvotomy. Two patients had both aortic and mitral valves replaced.

The internal and external diameters of the prosthesis were measured, as were pre- and post-operative pressures. Pressures were measured immediately before perfusion in nine of the 11 patients. The pressures of a further one were known pre-operatively and are listed in Table II. No pressures were taken either pre-operatively or pre-perfusion for the acute aortic valve replacement.

For simple aortic valve replacements, only the left ventricular and aortic pressures are listed. For the two double valve replacements the left atrial and right ventricular pressures are also listed.

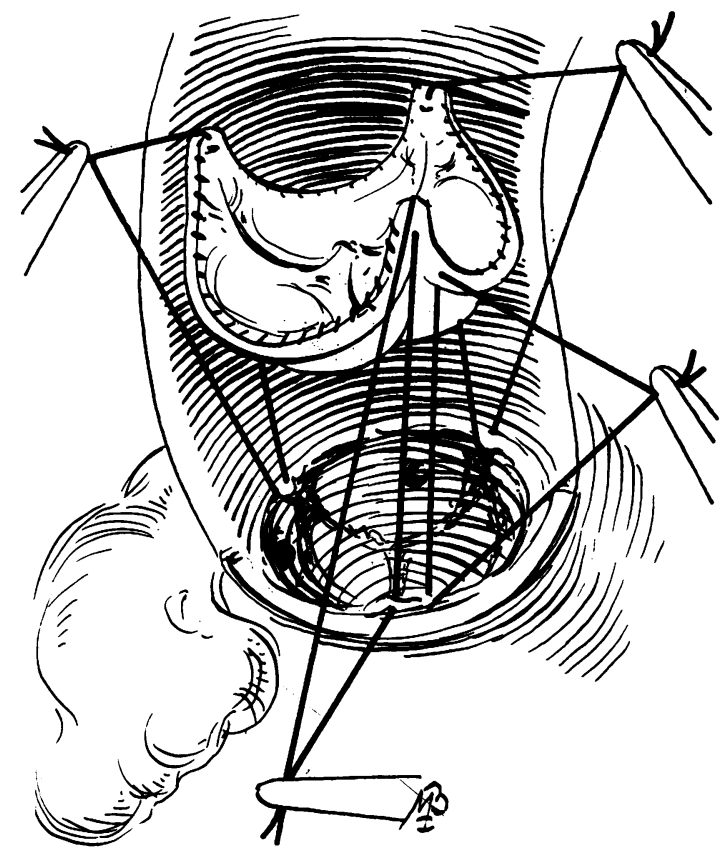

FIG. 4. Valve insertion technique.

\section{RESULTS}

Post-operative gradients were measured in nine patients. Five patients had a gradient of $10 \mathrm{~mm}$. $\mathrm{Hg}$ or less; of these, three were $14 \mathrm{~mm}$. internal diameter grafts, one was a $15 \mathrm{~mm}$. graft, and one

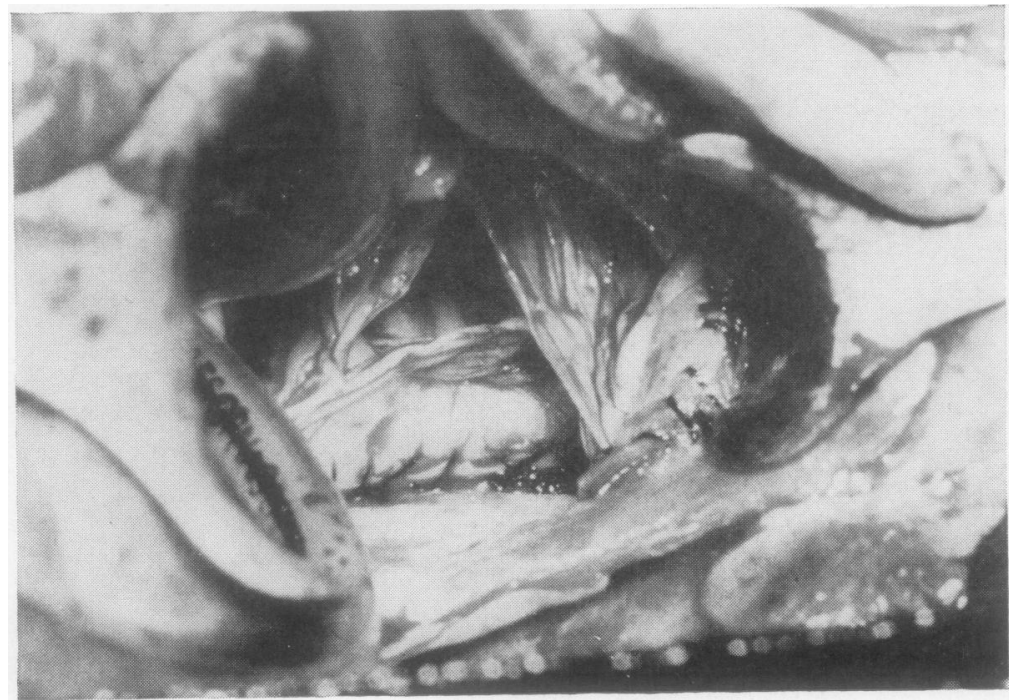

FIG. 5. Valve in aortic positid 
T A B L E I I

\begin{tabular}{|c|c|c|c|c|c|c|c|c|}
\hline Case & Lesion & $\begin{array}{c}\text { Aortic } \\
\text { Valve } \\
\text { Diameters } \\
(\mathrm{mm} .)\end{array}$ & Associated Surgery & $\begin{array}{l}\text { Pre-op. } \\
\text { B.P. } \\
\text { (mm.Hg) }\end{array}$ & $\begin{array}{l}\text { Post-op. } \\
\text { B.P. } \\
\text { (mm.Hg) }\end{array}$ & Pre-op. Pressures & Post-op. Pressures & Post-op. Murmurs \\
\hline 1 & A.I. & $\begin{array}{l}16 \text { int. } \\
26 \text { ext. }\end{array}$ & & $\frac{150}{55}$ & $\frac{120}{80}$ & L.V. $\frac{150}{15}$ Ao $\frac{160}{50}$ & L.V. $\frac{150}{0}$ Ao $\frac{140}{80}$ & $\begin{array}{l}\text { Systolic ejection } \\
\text { No early diastolic }\end{array}$ \\
\hline 2 & A.I. & $\begin{array}{l}13 \text { int. } \\
24 \text { ext. }\end{array}$ & & $\frac{170}{70}$ & & L.V. $\frac{160}{20}$ Ao $\frac{160}{80}$ & L.V. $\frac{150}{0}$ Ao $\frac{110}{70}$ & $\begin{array}{l}\text { Died 5th day } \\
\text { No early diastolic }\end{array}$ \\
\hline 3 & A.I. & $\begin{array}{l}14 \text { int. } \\
24 \text { ext. }\end{array}$ & Mitral valvotomy & $\begin{array}{l}200 \\
30\end{array}$ & $\frac{120}{70}$ & L.V. $\frac{140}{8}$ Ao $\frac{130}{40}$ & $\begin{array}{l}\text { L.V. } \frac{120}{10} \text { Ao } \frac{110}{80} \\
\text { Gradient } 10 \mathrm{~mm} \text {. }\end{array}$ & $\begin{array}{l}\text { Base-systolic ejec- } \\
\text { tion } \\
\text { Diastolic Gr. I-II } \\
\text { Apex-systolic } \\
\text { ? Mitral incom- } \\
\text { petence } \\
\text { ? Conducted }\end{array}$ \\
\hline 4 & A.S. & $\begin{array}{l}14 \text { int. } \\
24 \text { ext. }\end{array}$ & & $\frac{140}{80}$ & $\frac{140}{80}$ & $\begin{array}{l}\text { L.V. } \frac{200}{0} \text { Ao } \frac{110}{80} \\
\text { Gradient } 90 \mathrm{~mm} .\end{array}$ & $\begin{array}{l}\text { L.V. } \frac{120}{10} \underset{\text { Ao }}{\frac{110}{80}} \\
\text { Gradient } 10 \mathrm{~mm} .\end{array}$ & $\begin{array}{l}\text { Aortic systolic- } \\
\text { harsh with thrill } \\
\text { (Subvalvar muscle } \\
\text { stenosis) }\end{array}$ \\
\hline 5 & A.I. & 18 int. & & $\frac{150}{20}$ & $\frac{120}{80}$ & L.V. $\frac{170}{10}$ & L.V. 120 & $\begin{array}{l}\text { No early diastolic } \\
\text { Systolic ejection }\end{array}$ \\
\hline 6 & A.I. & $\begin{array}{l}30 \text { ext. } \\
14 \text { int. } \\
24 \text { ext. }\end{array}$ & & $\frac{90}{60}$ & $\frac{80}{140}$ & L.V. $\frac{90}{5}$ Ao $\frac{90}{50}$ & L.V. $\frac{0}{\frac{120}{10}}$ Ao $\frac{80}{110}$ & $\begin{array}{l}\text { No early diastolic } \\
\text { Systolic ejection } \\
\text { Gr. I diastolic }\end{array}$ \\
\hline 7 & $\begin{array}{l}\text { Mx } \\
\text { Ao }\end{array}$ & $\begin{array}{l}15 \text { int. } \\
24 \text { ext. }\end{array}$ & $\begin{array}{l}\text { Mitral tricuspid } \\
\text { valvotomy }\end{array}$ & $\frac{160}{70}$ & $\frac{130}{80}$ & L.V. $\frac{120}{0}$ Ao $\frac{100}{40}$ & L.V. $\frac{120}{0}$ Ao $\frac{120}{80}$ & $\begin{array}{l}\text { Base-systolic ejec- } \\
\text { tion } \\
\text { Gr. II diastolic }\end{array}$ \\
\hline 8 & $\begin{array}{l}\text { A.I. } \\
\text { A.I. }\end{array}$ & $\begin{array}{l}16 \text { int. } \\
26 \text { ext. } \\
18 \text { int. }\end{array}$ & & $\begin{array}{l}\frac{160}{55} \\
140 \\
0\end{array}$ & $\begin{array}{l}160 \\
90 \\
160 \\
\end{array}$ & L.V. $\frac{180}{0}$ Ao $\frac{180}{40}$ & L.V. $\frac{120}{15}$ Ao $\frac{120}{80}$ & $\begin{array}{l}\text { Apex-pansystolic } \\
\text { Systolic ejection } \\
\text { No early diastolic } \\
\text { Systolic ejection }\end{array}$ \\
\hline 10 & $\begin{array}{l}\text { Mx } \\
\text { Ao } \\
\text { Mx } \\
\text { Mit. }\end{array}$ & $\begin{array}{l}27 \text { ext. } \\
18 \text { int. } \\
28 \text { ext. }\end{array}$ & $\begin{array}{l}\text { Mitral replace- } \\
\text { ment } \\
26 \mathrm{~mm} \text {. int. } \\
35 \mathrm{~mm} \text {. ext. }\end{array}$ & $\begin{array}{c}0 \\
\frac{150}{50}\end{array}$ & $\frac{80}{140}$ & $\begin{array}{l}\text { L.V. } \frac{150}{0} \text { Ao } \frac{\frac{130}{60}}{60} \\
\text { L.A. } \frac{70}{10} \text { R.V. } \frac{60}{10}\end{array}$ & & $\begin{array}{l}\text { No early diastolic } \\
\text { Base-systolic ejec- } \\
\text { tion } \\
\text { Gr. II diastolic } \\
\text { Apex-systolic } \\
\text { ? Pan or? con- } \\
\text { ducted ejection }\end{array}$ \\
\hline 11 & $\begin{array}{l}\text { A.S. } \\
\text { Mx } \\
\text { Mit. }\end{array}$ & $\begin{array}{l}15 \text { int. } \\
25 \text { ext. }\end{array}$ & $\begin{array}{l}\text { Mitral replace- } \\
\text { ment } \\
20 \mathrm{~mm} \text {. int. } \\
35 \mathrm{~mm} \text {. ext. }\end{array}$ & $\frac{120}{70}$ & $\frac{120}{80}$ & $\begin{array}{l}\text { L.V. } \frac{160}{0} \text { Ao } \frac{120}{60} \\
\text { Gradient } 40 \text { mm. } \\
\text { L.A. } \frac{35}{10} \text { R.V. } \frac{40}{0}\end{array}$ & $\begin{array}{l}\text { L.V } \frac{120}{0} \text { Ao } \frac{110}{70} \\
\text { Gradient } 10 \text { mm. } \\
\text { L.A. } \frac{15}{5} \text { R.V. } \frac{40}{0}\end{array}$ & $\begin{array}{l}\text { Systolic ejection } \\
\text { No early diastolic }\end{array}$ \\
\hline
\end{tabular}

A.I. = Aortic incompetence; A.S. $=$ aortic stenosis ; Ao = aorta ; L.A. = left atrium ; L.V. = left ventricle ; Mit. = mitral; Mx Ao = Mixed aortic; Mx Mit. = Mixed mitral; R.V. = right ventricle.

was a $16 \mathrm{~mm}$. graft. Three patients had no gradient (15 mm., $16 \mathrm{~mm}$., and $18 \mathrm{~mm}$. grafts). One patient (case 2) had a gradient of $40-50 \mathrm{~mm}$. $\mathrm{Hg}$ across the aortic valve; this was the smallest graft used, measuring only $13 \mathrm{~mm}$. It should be noted that this patient also had significant subvalvular muscular hypertrophy, as did one patient with a gradient of $10 \mathrm{~mm}$. $\mathbf{H g}$ (case 4).

All cases of aortic incompetence showed significant improvement of diastolic blood pressure, varying from an increase of $20 \mathrm{~mm}$. $\mathrm{Hg}$ to one of $80 \mathrm{~mm}$. $\mathrm{Hg}$ (Table II).

All aortic replacements had an ejection systolic murmur over the aortic area. No aortic diastolic murmur was audible in seven cases. Four patients had aortic diastolic murmurs which were thought not to be haemodynamically important at present. Both patients with mitral replacements had a systolic murmur in the mitral area which was thought to be a conducted aortic murmur.
Case 2, who died on the fifth post-operative day, had an aortic heterograft replacement with an internal diameter of only $13 \mathrm{~mm}$. and a postoperative gradient of $40-50 \mathrm{~mm}$. $\mathrm{Hg}$. At operation it had been noted that severe muscular hypertrophy of the outflow tract of the left ventricle was present. This patient subsequently died in pulmonary oedema associated with left ventricular failure thought to be due to combined subvalvular muscular stenosis plus stenosis of the aortic valve resulting from insertion of too small a graft.

\section{DISCUSSION}

This report deals with 11 consecutive valve replacements (grafts on carrier rings), in which only one post-operative death occurred, thus showing the general practicability of the operation.

All aortic replacements had an ejection systolic murmur post-operatively, a feature noted with 
free homografts (Davies et al., 1965; BarrattBoyes et al., 1965). Of the nine patients in whom post-operative pressures were measured, three had no post-operative gradient (internal diameters 15 $\mathrm{mm} ., 16 \mathrm{~mm}$., and $18 \mathrm{~mm}$.) and five had an insignificant gradient of $10 \mathrm{~mm}$. $\mathrm{Hg}$ or less (three of the five were internal diameters $14 \mathrm{~mm} ., 15 \mathrm{~mm}$., and $16 \mathrm{~mm}$.). The only significant gradient occurred with the smallest graft used (case 2), $13 \mathrm{~mm}$. internal diameter. Thus it would appear, in general, that $14 \mathrm{~mm}$. to $15 \mathrm{~mm}$. is the minimum internal diameter that will suffice.

No aortic diastolic murmur was audible in seven cases, while four patients had aortic diastolic murmurs which were thought not to be haemodynamically important at present. A significant improvement of diastolic blood pressure was seen in all cases of pre-operative aortic incompetence, the patients with post-operative diastolic murmurs having a satisfactory diastolic blood pressure ranging from $70 \mathrm{~mm}$. to $80 \mathrm{~mm}$. $\mathrm{Hg}$. One feature of free aortic homografts has been the high incidence of post-operative diastolic murmurs. Barratt-Boyes (1965) quoted $52 \%$ incidence, of which only $14 \%$ were more than trivial. Ross (1967) has reduced the incidence of regurgitant murmurs to $24 \%$, in which haemodynamically significant incompetence is unusual. BarrattBoyes classified four causes of post-operative aortic incompetence :

(1) Imperfect cusp approximation due to twisting of the graft at the time of operation-this type of murmur usually disappears.

(2) Graft detachment at the suture line, giving a peripheral leak.

(3) The homograft is too small for the host, so that the cusps do not meet and a central leak occurs.

(4) Cusp failure occurring late after operation.

We feel that our type of preparation avoids the first complication, as the graft is inserted accurately on to the ring pre-operatively. Central leak is eliminated because the additional bulk of the ring precludes the necessity for stretching the graft to fit larger aortic roots. In addition, more accurate apposition of the cusps may delay the incidence of late cusp failure. Late failure due to calcification may be related to turbulent flow (Ross, 1967), and the more accurate approximation of cusps made possible by the present method may reduce the turbulence and hence, possibly, late calcification.

We have considered the possible advantages of mounting a homograft on a Dacron ring, but a number of possible disadvantages must now be considered. These include $(a)$ the possibility of infection, (b) incorporation into host tissues, and (c) the effect on the long-term fate of the cusps.

(a) An intracardiac rigid metal frame produces an area of turbulence which in the presence of an inert cloth produces an environment predisposing to infection (Barney, Williams, Cayler, and Bracken, 1962; Amoury, Bowman, and Malm, 1966). Thus it may be that this type of prosthesis has a higher risk of infection than a free homograft, and may have the bad prognosis associated with infection in a Starr-Edwards valve. Infection in a free homograft is more likely to be treated successfully in the usual way. No case of subacute bacterial endocarditis has been seen in the series, although one patient (case 9) had an aortic 음 valve replacement for acute valve rupture after two weeks' intensive treatment of subacute bacterial endocarditis.

(b) Experience with Dacron graft material has shown it to be readily incorporated into host tissues, and a similar carrier ring used in animals is known to be rapidly and firmly incorporated into the host aorta (Geha et al., 1967).

(c) It is impossible from our short follow-up to state with any certainty the effect of the Dacron ring on the long-term fate of the cusps, but it seems unlikely that the presence of an inert barrier would adversely affect the long-term fate of the dead avascular valve cusps.

We believe our method offers a satisfactory alternative for replacing the aortic valve when conditions for inserting a free homograft are not applicable-namely, detailed aortic root, friable aortic wall, and for use in the atrio-ventricular position in multi-valve surgery.

We think that if insertion of a prosthesis with an internal diameter of less than $15 \mathrm{~mm}$. is contemplated, a free homograft is more advisable, as $\delta$ post-operative gradients may appear. With the present valve there is a loss of $8-10 \mathrm{~mm}$ : across 윽 the diameter of the prosthesis owing to the bulk $D$ of the ring. Further work is proceeding with a new valve to reduce the loss in diameter to only $5 \mathrm{~mm}$.

Our thanks are due to Dr. V. G. Grimshaw and Dr. M. D. Hargreaves, who were responsible for the 0 perfusion and much help in the post-operative care, and to Dr. W. L. Whitaker, Dr. S. H. Taylor, and Dr. D. R. Smith, who investigated the patients before $\stackrel{D}{\mathscr{D}}$ operation. We should also like to thank the Uni-? versity Medical Photographic Department and Miss 0 Mary Brown, the medical artist, for the photographs

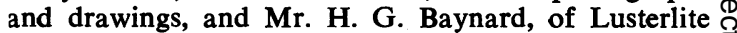
Products Limited, from whom the rings are available. $\mathbb{D}$ Finally, we thank Miss S. Robinson for typing the script. 


\section{REFERENCES}

Amoury, R. A., Bowman, F. O., and Malm, J. R. (1966). Endocarditis associated with intracardiac prostheses; diagnosis, management, and prophylaxis. J. thorac. cardiovasc. Surg., 51, 36.

Barney, J. D., Williams, G. R., Cayler, G. G., and Bracken, E. C. (1962). Influence of intracardiac prosthetic materials on susceptibility to bacterial endocarditis. Circulation, 26, 684 .

Barratt-Boyes, B. G. (1964). Homograft aortic valve replacement in aortic incompetence and stenosis. Thorax, 19, 131 .

- (1965). A method for preparing and inserting a homograft aortic valve. Brit. J. Surg., 52, 847.

- Lowe, J. B., Cole, D. S., and Kelly, D. T. (1965). Homograft valve replacement for aortic valve disease. Thorax, 20,495 .

Beall, A. C., Morris, G. C., Cooley, D. A., and DeBakey, M. E. (1961). Homotransplantation of the aortic valve. J. thorac. cardiovasc. Surg., 42, 497.

Bigelow, W. G., Yao, J. K., Aldridge, H. E., Heimbecker, R. O., and Murray, G. D. W. (1964). Clinical homograft valve transplantation. Ibid., 48, 333.

Binet, J. P., Duran, C. G., Carpentier, A., and Langlois, J. (1965). Heterologous aortic valve transplantation. Lancet, 2, 1275.

Braunwald, N. S., Fuchs, J. C. A., and Bonchek, L. I. (1967). Simplified insertion of aortic homograft valves with nonthrombogenic prosthetic frames. Trans. Amer. Soc. artif. intern. Organs, 13, 111. (1968). Simplified insertion of aortic homograft valves with nonthrombogenic prosthetic frames. Surgery, 63,38 .

Brock, Lord (1968). Long-term degenerative changes in aortic segment homografts, with particular reference to calcification. Thorax, 23, 249.

Davies, H., Lessof, M. H., Roberts, C. I., and Ross, D. N. (1965). Homograft replacement of the aortic valve. Lancet, 1, 926.

Duran, C. G., and Gunning, A. J. (1962). Method for placing a total homologous aortic valve in the subcoronary position. Lancet, 2 , 488. dog. Ibid., 2, 114

- Manley, G., and Gunning, A. J. (1965). The behaviour of homotransplanted aortic valves in the dog. Brit. J. Surg., 52, 549.

Geha, A. S., Titus, J. L., and McGoon, D. C. (1967). Fixation of aortic valve homografts with metal rings. $J$. thorac. cardiovasc. Surg., 54, 605.

Hudson, R. E. B. (1966). Pathology of the human aortic valve homograft. Brit. Heart J., 28, 291

Kerwin, A. J., Lenkei, S. C., and Wilson, D. R. (1962). Aortic-valve homograft in the treatment of aortic insufficiency. New Engl. J. Med., 266, 852.
Kwong, K. H., Paton, B. C., and Hill, R. B. (1967). Experimental use of immuno-suppression in aortic valve homografts and heterografts. J. thorac. cardiovasc. Surg., 54, 199.

Lam, C. R., Aram, H. H., and Munnell, E. R. (1952). An experimental study of aortic valve homografts. Surg. Gynec. Obstet. 94, 129.

Murray, G. (1956). Homologous aortic-valve segment transplants as surgical treatment for aortic and mitral insufficiency. Angiology, 7,466 .

(1960). Aortic valve transplants. Ibid., 11, 99.

O'Brien, M. F. (1967). Heterograft aortic valves for human use. Valve bank, techniques of measurement, and implantation. $J$. thorac. cardiovasc. Surg., 53, 392

— and Clarebrough, J. K. (1966). Heterograft aortic valve transplantation for human valve disease. Aust. med. J., 2, 228.

McDonald, I. G., Hale, G. S., Bray, H. S., and Cade, J. F. (1967). Heterograft aortic valve replacement: initial followup studies. Thorax, 22, 387 .

- and Gerbode, F. (1964). Homotransplantation of the mitral valve. Aust. N.Z. J. Surg., 34, 81.

Paneth, M., and O'Brien, M. F. (1966). Transplantation of human homograft aortic valve. Thorax, 21, 115 .

Paton, B. C., Kwong, K. H., Clark, D., Halseth, W. L., and Hill, R. B. (1967). Immunosuppressive therapy in the management of homo- and heterografted cardiac valves. Transplantation, 5, 909.

Pritchard, G. R., Wright, J. S., and Johnston, J. B. (1967). Transplantation of aortic valve cusps - an experimental comparison of homografts and heterografts. J. thorac. cardiovasc. Surg., 53, 322.

Rains, A. J. H., Crawford, N., Sharpe, S. H., Shrewsbury, J. F. D. and Barson, G. J. (1956). Management of an artery-graft bank with special reference to sterilization by beta-propiolactone. Lancet, $2,830$.

Ross, D. N. (1962). Homograft replacement of the aortic valve. Ibid., 2, 487.

- (1964). Homotransplantation of the aortic valve in the subcoronary position. J. thorac. cardiovasc. Surg., 47, 713.

- (1966). Aortic-valve replacement. Lancet, 2, 461.

(1967). Homograft replacement of the aortic valve. Brit. J. Surg., 54, 842.

- (1967). Replacement of aortic and mitral valves with a pulmonary autograft. Lancet, $2,956$.

Smith, J. C. (1967). The pathology of human aortic valve homografts. Thorax, 22, 114.

Weldon, C. S., Mel Ameli, M., Morovati, S. S., and Shaker, I. J. (1966). A prosthetic stented aortic homograft for mitral valve replacement. J. surg. Res., 6, 548 . 